\title{
Diversity, trait displacements and shifts in assemblage structure of tidal flat deposit feeders along a gradient of hydrodynamic stress
}

\author{
C. Van Colen ${ }^{1, *}$, A. De Backer ${ }^{2,1}$, G. Meulepas ${ }^{1}$, D. van der Wal ${ }^{3}$, M. Vincx ${ }^{1}$, \\ S. Degraer ${ }^{4,1}$, T. Ysebaert ${ }^{3,5}$ \\ ${ }^{1}$ Ghent University, Department of Biology, Marine Biology Section, Krijgslaan 281/S8, 9000 Ghent, Belgium \\ ${ }^{2}$ Institute for Agriculture and Fisheries Research (ILVO), Biological monitoring section, Ankerstraat 1, 8400 Oostende, \\ Belgium \\ ${ }^{3}$ Netherlands Institute of Ecology (NIOO-KNAW), Centre for Estuarine and Marine Ecology, POB 1404400 AC Yerseke, \\ The Netherlands \\ ${ }^{4}$ Management Unit of the North Sea Mathematical Model, Marine Ecosystem Management Section, \\ Royal Belgian Institute of Natural Sciences, Gulledelle 100, 1200 Brussels, Belgium \\ ${ }^{5}$ Wageningen University, Institute for Marine Resources \& Ecosystem Studies, POB 774400 AB Yerseke, The Netherlands
}

\begin{abstract}
To assess the effect of variability in hydrodynamic stress on benthic assemblages we investigated whether deposit-feeding macrobenthos performs a unimodal response to an intertidal flat hydrodynamic stress gradient, congruent with the intermediate disturbance hypothesis (IDH), and whether this response is related to assemblage-wide biological trait displacements, reflecting species sorting mechanisms. Patterns in diversity and assemblage-wide biological traits were explained to a large extent by hydrodynamic stress and reflected in a significantly differing assemblage structure between stress levels. Our data did not support the IDH, since species richness and diversity peaked at low stress, whereas evenness was lowest at intermediate stress, suggesting that species sorting in response to hydrodynamic stress, rather than competitive exclusion at low stress, drives the diversity stress response. The decrease in species richness and diversity towards the hydrodynamically harsher low intertidal was reflected in the assemblage-wide shifts towards a lower dietary dependency on microalgal carbon and a deeper living position. Intermediate stressed assemblages were associated with a shift towards a more resistant development mode to superficial sediment disturbance. This is suggested to result from species sorting in response to Cerastoderma edule interference from bioturbation, which peaked at intermediate hydrodynamic stress where optimal hydrodynamic conditions for suspension feeders prevail. The present study demonstrated that the alteration of the natural hydrodynamic regime will significantly affect tidal flat benthic community composition and, hence, ecosystem functioning. Additionally, our findings reveal that inhibitory biophysical interactions, such as interference from bioturbation, should be incorporated in environmental stress biodiversity models.
\end{abstract}

KEY WORDS: Environmental stress models · Intermediate disturbance hypothesis · Biological traits · Interference from bioturbation $\cdot$ Species sorting $\cdot$ Tidal flat ecology

\section{INTRODUCTION}

Understanding the factors and mechanisms that control patterns of diversity at a local scale is of central importance to ecology since this knowledge provides insights into the ecological processes that regulate species populations and assemblages. Numerous studies have demonstrated that the local distribution of benthic organisms in shallow marine environments is related to (1) the prevailing environmental conditions, 
whether or not directly or indirectly mediated by the benthos (i.e. ecosystem engineering, sensu Jones et al. 1994), and (2) direct biotic interactions (e.g. Widdows et al. 1998, 2002, van der Meer et al. 2000, Ysebaert \& Herman 2002, Ysebaert et al. 2003, Volkenborn \& Reise 2007, Volkenborn et al. 2007). However, marine environments nowadays increasingly experience a wide variety of anthropogenic stressors and disturbances which have also been documented to affect assemblage structure, species diversity and ecosystem functioning (Kennish 2002, Halpern et al. 2008, Thrush et al. 2008). Moreover, such human-induced declines in diversity are expected to affect ecosystem functioning and resilience to environmental change (e.g. Gray 1997, Elliott et al. 2007, Stachowicz et al. 2007).

Estuarine tidal flats typically are constituted of dense deposit-feeding macrobenthic populations which substantially contribute to tidal flat nutrient cycling by affecting sediment transport processes through bioturbatory activities (Meysman et al. 2006) and representing an important trophic linkage through the provision of forage for epibenthic crustaceans, fish and birds and by feeding on benthic algae and bacteria (e.g. Herman et al. 2000, Hampel et al. 2005, van Oevelen et al. 2006). However, enhanced wave energy associated with the predicted sea level rise and increase in storm severity will coarsen and erode the sediment of intertidal habitats that cannot transgress further inland (Kennish 2002, Fujii \& Raffaelli 2008). This, in turn, is likely to decrease deposit feeder food availability and increase bed load and water column dispersal (e.g. Tamaki 1987, Günther 1992, Commito et al. 1995), thus affecting tidal flat deposit feeding assemblage structure and function.

In order to assess changes in tidal flat ecology due to enhanced hydrodynamic stress, a solid understanding of how natural hydrodynamic stress across a tidal flat shapes the distribution and diversity of macrobenthos assemblages is required. The intermediate disturbance hypothesis ( $\mathrm{IDH}_{i}$ Connell 1978) predicts that sessile community diversity is maximized at intermediate levels of disturbance intensity and/or frequency because this state enables the coexistence of stress-tolerant species and potential competitors, whereas competitively dominant species may exclude subordinate species at low disturbance and less tolerant species may directly be eliminated at high disturbance. However, Mackey \& Currie (2001) revealed that a unimodal disturbance-diversity relationship was only observed in 11 to $19 \%$ (depending on the diversity measure applied) of 116 reviewed papers, which highlights the hypothesis status of the IDH principle. In marine substrates, experimental evidence for the IDH has been shown for rocky shores (e.g. Paine 1966, Sousa 1979) and coral reefs (Aronson \& Precht 1995, Connell et al.
2004), whereas for soft-sediment environments, evidence has so far only been invoked from mesocosm disturbance and organic enrichment experiments (e.g. Austen \& Widdicombe 1998, Schratzberger \& Warwick 1998, 1999, Widdicombe \& Austen 1999, 2001). This may be attributed to the fact that benthic communities in the field have to cope with multiple stressors which may affect species differently, thereby hampering the detection of a unimodal overall (alpha) diversity response to a continuous stressor.

In marine benthic ecosystems, taxonomic community composition-derived diversity measurements such as species richness, diversity indexes (e.g. ShannonWiener) and taxonomic distinctness have traditionally been used to describe diversity in relation to different or changing environments or stress (e.g. Warwick \& Clarke 1993, Somerfield \& Clarke 1995). Speciesspecific ecological or functional characteristics (e.g. feeding habit, life habit) have often, subsequently, been linked in order to determine indirectly the processes that underpin the observed diversity patterns. However, though the same 2 species may perform certain similar ecological roles, these species may also differ in other ways and therefore react differently to stress, thereby hampering the detection of the driving mechanism of the stress response (Bremner et al. 2003). Since species assemblages are expected to be structured by the ability of species to cope with stressors, analysis of assemblage-wide shifts in biological traits along the stress gradient is therefore essential to unravel the driving processes of the diversity-stress response. In the present study, the macrobenthic deposit feeder community across an entire intertidal gradient on a single tidal mudflat was used to investigate how diversity, biological traits and community structure vary in relation to the prevailing hydrodynamic stress. In particular, we addressed the following questions: Does benthic species diversity exhibit a unimodal hydrodynamic stress response, congruent to the IDH? Does the macrobenthos community structure differ in relation to hydrodynamic stress? Do communitywide biological trait shifts occur along the hydrodynamic stress gradient, which may explain the observed benthic stress response?

\section{MATERIALS AND METHODS}

Site description and biotic sampling. Samples were collected on 17, 19 and 23 April 2002 at the Paulinapolder tidal flat, which is located along the south bank of the lower, polyhaline part of the Westerschelde estuary (SW Netherlands) (Fig. 1). The flat has a semidiurnal tidal regime with a mean tidal range of $3.9 \mathrm{~m}$ and a yearly average salinity of 24 PSU (Ysebaert 


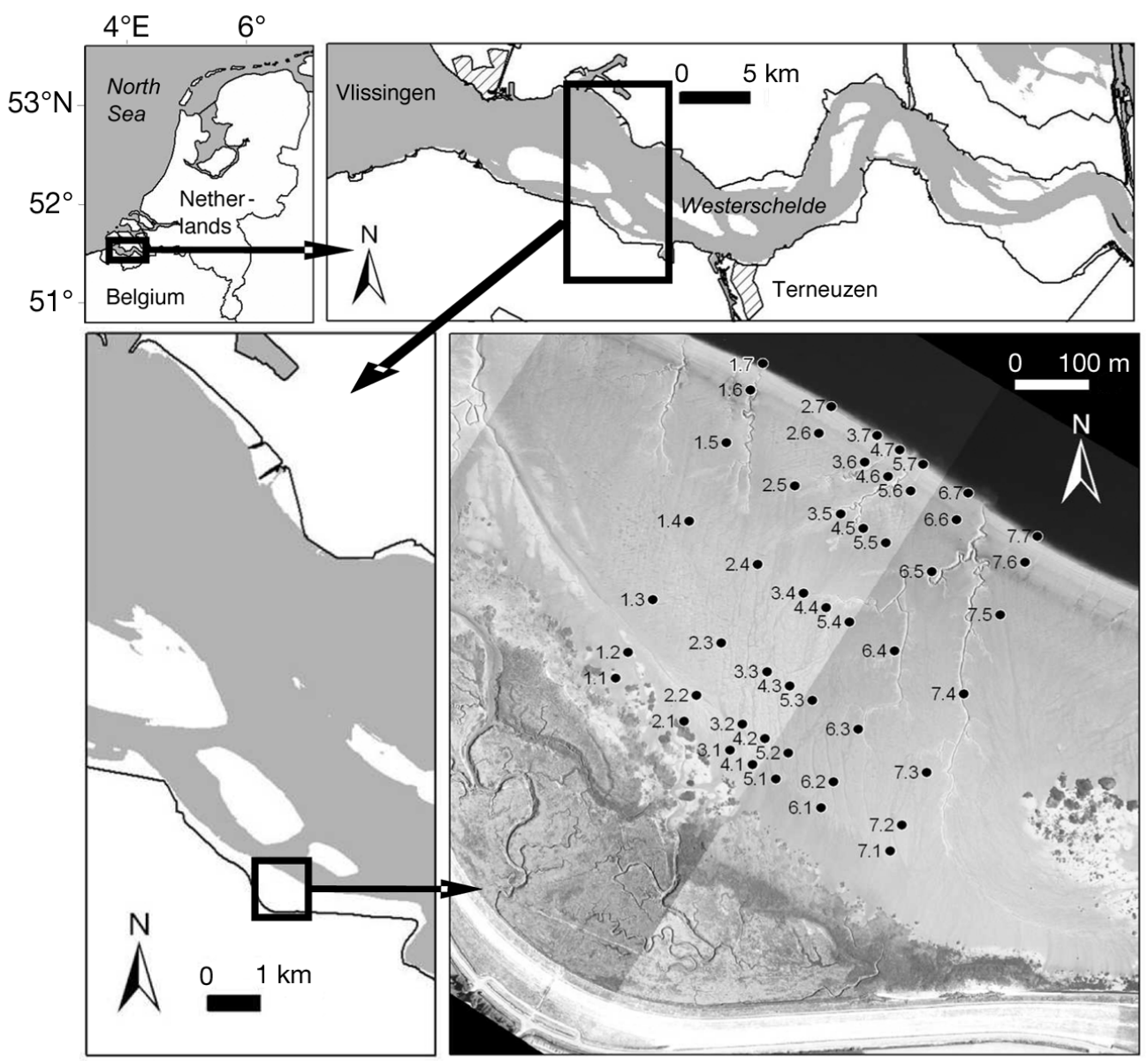

Fig. 1. The intertidal study site and layout of the sampling stations $(\bullet)$ along the 7 cross-shore transects

2000). The established macrofaunal community consists of 20 species, of which 14 deposit-feeding species comprise 83 to $99 \%$ of the total macrobenthic abundance and are characterized by a wide variety of biological traits (Table A1 in Appendix 1). In addition, the suspension-feeding cockle Cerastoderma edule represents up to 16 and $96 \%$ of the community abundance and biomass, respectively.

Macrobenthos samples were collected with a stainless corer (inner diameter $11 \mathrm{~cm}$ ) to a depth of $40 \mathrm{~cm}$ along 7 intertidal transects. Each transect consisted of 7 sampling stations, covering a complete cross-shore gradient from the marsh edge towards the subtidal estuarine main channel (Fig. 1). The macrobenthos samples $\left(\mathrm{n}=1\right.$ sampling station $^{-1}$ ) were washed over a 0.5 mm mesh-sized sieve and the residual organisms were fixed in a buffered $4 \%$ formalin-seawater solution. In the laboratory, the retained organisms were sorted, counted and identified after staining with Rose Bengal.

Characterization of the hydrodynamic stress gradient. Hydrodynamic bed shear stress is affected by the local topography (i.e. slope and tidal elevation/range), as well as by the prevailing flood and ebb current velocities, and influences sediment composition and associated pore water metabolites (e.g. oxygen) and organic matter (i.e. food for deposit feeders) (Reise 1985, Raffaelli \& Hawkins 1996). In order to characterize the prevailing stress gradients associated with the hydrodynamic regime across the tidal flat, parameters related to hydrodynamic stress were recorded. At each sampling station, the first sediment layer was sampled, freeze-dried and stored at $-20^{\circ} \mathrm{C}$, and subsequently processed in the laboratory for granulometry using Malvern laser diffraction analysis. Further environmental characteristics were extracted at the sampling stations in GIS, based on maps from Rijkswaterstaat, the Dutch Ministry of Transport, Public Works and Water Management (Graveland 2005). Elevation data were obtained from a laser altimetry survey of 2001 for the intertidal zone, combined with interpolated single beam echo soundings for the subtidal zone. Spatial information on current velocity, i.e. the maximum current velocity during flood and ebb on spring and mean tides, were derived from simulations (using the 2001 
Table 1. Spearman rank correlations with the first principal component $\left(\mathrm{PC}_{\mathrm{hydr}}\right)$ and elevation (cm above Dutch Ordnance Datum NAP) of sampled variables across the intertidal flat at Paulinapolder. Relations with $\mathrm{PC}_{\text {hydr }}$ are significant at $\mathrm{p}<0.004$ after Bonferroni correction. Range indicates the maximum and minimum recorded values

\begin{tabular}{|c|c|c|c|c|c|}
\hline \multirow{2}{*}{ Parameter } & \multirow[t]{2}{*}{ Range } & \multicolumn{2}{|c|}{$\mathrm{PC}_{\text {hydr }}$} & \multicolumn{2}{|c|}{ Tidal elevation } \\
\hline & & $\mathrm{r}$ & $\mathrm{p}$ & $\mathrm{r}$ & $\mathrm{p}$ \\
\hline Maximum ebb current velocity mean tide $\left(\mathrm{cm} \mathrm{s}^{-1}\right)$ & $6-45$ & -0.98 & $<0.001$ & -0.97 & $<0.001$ \\
\hline Maximum flood current velocity mean tide $\left(\mathrm{cm} \mathrm{s}^{-1}\right)$ & $11-49$ & -0.95 & $<0.001$ & -0.93 & $<0.001$ \\
\hline Maximum ebb current velocity spring tide $\left(\mathrm{cm} \mathrm{s}^{-1}\right)$ & $11-51$ & -0.98 & $<0.001$ & -0.97 & $<0.001$ \\
\hline Maximum flood current velocity spring tide $\left(\mathrm{cm} \mathrm{s}^{-1}\right)$ & $16-58$ & -0.98 & $<0.001$ & -0.97 & $<0.001$ \\
\hline Median particle size $(\mu \mathrm{m})$ & $37-132$ & -0.88 & $<0.001$ & -0.80 & $<0.001$ \\
\hline Mud content $(\%<63 \mu \mathrm{m})$ & $15-75$ & 0.87 & $<0.001$ & 0.79 & $<0.001$ \\
\hline Very fine sand fraction (\% 63-125 $\mu \mathrm{m})$ & $20-43$ & -0.84 & $<0.001$ & -0.74 & $<0.001$ \\
\hline Fine sand fraction $(\% 125-250 \mu \mathrm{m})$ & $3-45$ & -0.87 & 0.057 & -0.80 & 0.040 \\
\hline Medium sand fraction (\% 250-500 $\mu \mathrm{m}$ ) & $0-11$ & -0.28 & $<0.001$ & -0.29 & $<0.001$ \\
\hline Sorting coefficient $(\rho)$ & $1.1-3.3$ & 0.68 & $<0.001$ & 0.55 & $<0.001$ \\
\hline Submersion duration at spring tide $(\mathrm{h})$ & $4.8-10.8$ & -0.96 & $<0.001$ & -1.00 & $<0.001$ \\
\hline Submersion duration at mean tide (h) & $4.6-12.0$ & -0.96 & $<0.001$ & -1.00 & $<0.001$ \\
\hline
\end{tabular}

elevation data) with SCALWEST, a numerical flow model developed for the Westerschelde. The 2001 elevation data were also combined with water level information from 2002 from the nearby tide gauge station Terneuzen (Fig. 1) to calculate inundation duration at the sampling stations at spring and mean tide. Principal component analysis (PCA, Goodall 1954) was carried out on the environmental characteristics (except elevation) of the sampling stations and revealed the prevalence of one main hydrodynamic stress axis $\left(\mathrm{PC}_{\text {hydri }}\right.$ eigenvalue $=8.99$, explanatory value $\left.=74.9 \%\right)$, which strongly correlated with tidal current aspects and sediment composition after Bonferroni correction (Table 1). Hydrodynamic stress intensifies with a lower intertidal elevation and decreasing values of $\mathrm{PC}_{\text {hydr }}$ indicate increased submersion time, increased current velocity during ebb and flood and a substrate composed of less sorted, less muddy sediment. Important to note here is that dessication is not expected to be a driving stressor at our study site because the low hydraulic conductivity of the muddy sediment keeps the sediment fully water-saturated during the entire ebb period. Because we aimed to study tidal flat macrobenthic deposit feeder diversity, assemblage structure and assemblage-wide patterns of biological traits in relation to hydrodynamical stress sensu lato, we retained sampling stations scores from the first PCA axis for further analysis. Stations were characterized as having low, intermediate or high hydrodynamic stress according to their distribution within the upper $\left(\mathrm{PC}_{\mathrm{hydr}}\right.$ $>2.25)$, intermediate $\left(-1.65>\mathrm{PC}_{\mathrm{hydr}}<2.25\right)$ and lower $\left(\mathrm{PC}_{\mathrm{hydr}}<-1.65\right)$ 33th percentile of $\mathrm{PC}_{\mathrm{hydr}}$.

Data analysis. Species richness and diversity have often been used as synonyms in past studies and, in the context of the IDH, both terms have been used interchangeably (e.g. Menge \& Sutherland 1987, Bertness 2007). However, since diversity depends on the num- ber of species in the community and the degree of similarity in abundance among species (i.e. evenness), their patterns in relation to environmental stress may differ (e.g. Kimbro \& Grosholz 2006). Hence we calculated species richness (i.e. total number of species, $S$ ), species diversity (Shannon-Wiener diversity index, $H^{\prime}=-\Sigma p_{i} \log _{\mathrm{e}}\left(\mathrm{p}_{i}\right)$, where $\mathrm{p}_{i}$ is the proportional abundance of species $i$ ) and evenness (Pielou's evenness, $J^{\prime}=H^{\prime} / \log _{\mathrm{e}} S$ ) of the deposit feeding assemblage for each sampling station. In order to avoid biased results, Arenicola marina, a deep-dwelling subsurface deposit feeder, was omitted from the analyses since this species was considered to be sampled non-representatively. To delineate insights in the underlying drivers of the diversity and community structure stress response, the relationship between hydrodynamic stress and 3 important life history traits of deposit-feeding macrobenthos with respect to hydrodynamic stress was analyzed: microalgal carbon dietary requirement, living position in the sediment and development mode. The microalgal contribution to the species' diet at the study site was quantified by comparing the consumers' $\Delta \delta^{13} \mathrm{C}$ (i.e. the increment of $\delta^{13} \mathrm{C}$ due to a PLFA biomarker uptake, as compared to natural background values) to the $\Delta \delta^{13} \mathrm{C}$ of microalgae i.e. the $\Delta$-ratio $\Delta \delta^{13} \mathrm{C}_{\text {consumer }} / \Delta \delta^{13} \mathrm{C}_{\text {resource }}$ (R. Rossi \& J. J. Middelburg unpubl. data). The species living position in the sediment was retrieved from vertical sediment profiles taken at the study site in March and scored on a categorical scale that reflects a deeper living position and, hence, lower sensitivity to (hydrodynamic) disturbance at the sediment-water interface: $0=$ upper $2 \mathrm{~cm}$, $1=2$ to $5 \mathrm{~cm}$ depth, $2=>5 \mathrm{~cm}$ deep. Analogously, species development modes were retrieved from Dekker \& Beukema (1999), Eckert (2003) and the Marine Life Information Network (www.marlin.ac.uk) and scaled on a categorical scale that reflects decreasing sensitiv- 
ity to (hydrodynamic) disturbance at the sedimentwater interface: 0 = non- or limited pelagic larval development, 1 = pelagic larval development, 2 = direct benthic development. Species-specific $\Delta$-ratios, development modes and living positions, as well as more details on the assigned scale values, are presented in Table A1.

The assemblage-wide trait approach was based on the weighted average for the contribution of microalgae to the species' diet and the interpolated median of development mode and living position scores (Zar 1996). The influence of hydrodynamic stress on species richness, diversity, evenness and assemblage-wide biological traits was assessed using linear and quadratic models (Statistica 7.0). The first PCA axis was used as the continuous factor, reflecting hydrodynamic stress sensu lato, whereas diversity parameters and the trait values of co-occurring species were used as dependent variables. Extreme outliers were excluded from the analysis (casewise plot of residuals \pm 3 sigma, Statistica 7.0) to achieve normality of residuals (normal probability plot, Statistica 7.0) and Akaike's information criterion (AIC) (Johnson \& Omland 2004) was applied to infer the most reliable model. One sampling station (Stn 5.1), which contained only 3 individuals of 2 different species, was omitted from all analyses since it consistently behaved as an outlier in all analyses.
One-way analysis of similarities (ANOSIM) based on $\log (x+1)$-transformed standardized abundance data (Clarke \& Warwick 2001) was applied to investigate differences in community structure between low, intermediate and high hydrodynamically stressed stations. Further, the species contributing most to the dissimilarities were identified using similarity of percentages analysis (SIMPER, Clarke 1993) and indicative species for the 3 assemblages were identified by calculation of their indicator value (IV) using the INDVAL program (Dufrêne \& Legendre 1997).

\section{RESULTS}

\section{Species diversity and community structure}

Species richness and diversity decreased significantly with increasing hydrodynamic stress, whereas evenness was lowest at intermediate hydrodynamic stress and peaked at both high and low hydrodynamic stress levels (Fig. 2, Table 2). ANOSIM revealed a significant difference between low, intermediate and high hydrodynamically stressed stations (low-intermediate: $R=0.39, \mathrm{p}=0.001$; low-high: $R=0.46, \mathrm{p}=$ 0.001; intermediate-high: $R=0.24, \mathrm{p}=0.002$ ), with different species comprising the majority of the
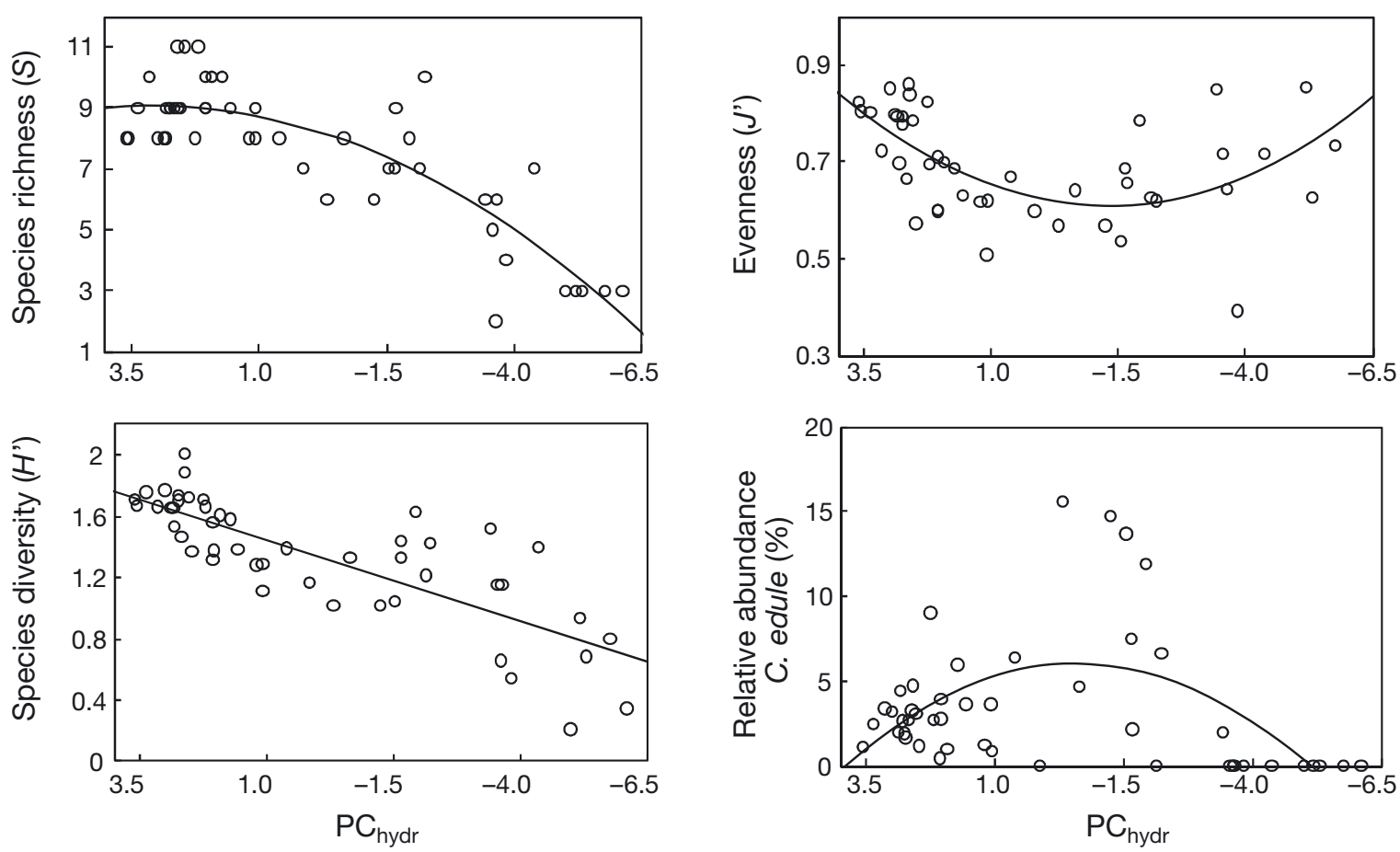

Fig. 2. Relationship between the degree of hydrodynamic stress along the intertidal gradient and deposit-feeder species richness $(S)$, Shannon-Wiener diversity $\left(H^{\prime}\right)$, Pielou's evenness $\left(J^{\prime}\right)$ and the relative abundance of Cerastoderma edule. The principal component scores derived from a principal component analysis of station-specific habitat characteristics $\left(\mathrm{PC}_{\mathrm{hydr}}\right)$ are used to indicate the degree of hydrodynamic stress along the $\mathrm{x}$-axis. Regression lines of the most reliable model are given (Table 2) 
Table 2. Influence of hydrodynamic stress on deposit-feeding species richness $(S)$, Shannon-Wiener species diversity $(H)$, evenness (Pielou's $J^{\prime}$ ) and relative abundance of the cockle Cerastoderma edule. Degrees of freedom are indicated next to the regression type (numerator, denominator). AIC: Akaike's information criterion

\begin{tabular}{|c|c|c|c|c|c|}
\hline \multirow{2}{*}{ Parameter } & \multirow[t]{2}{*}{ Regression type } & \multicolumn{4}{|c|}{ Regression statistics } \\
\hline & & $F$ & $\mathrm{p}$ & $\mathrm{R}_{\text {adj }}^{2}$ & AIC \\
\hline \multirow[t]{2}{*}{ Species richness } & Linear $(1,46)$ & 69.68 & $<0.0001$ & 59.37 & 176.61 \\
\hline & Quadratic $(2,45)$ & 64.05 & $<0.0001$ & 63.45 & 173.78 \\
\hline \multirow{2}{*}{ Shannon-Wiener diversity } & Linear $(1,46)$ & 56.22 & $<0.0001$ & 54.99 & 12.44 \\
\hline & Quadratic $(2,45)$ & 27.82 & $<0.0001$ & 55.29 & 14.13 \\
\hline \multirow[t]{2}{*}{ Pielou's evenness } & Linear $(1,45)$ & 3.98 & 0.0522 & 6.08 & -73.92 \\
\hline & Quadratic $(2,43)$ & 8.74 & 0.0007 & 25.59 & -211.46 \\
\hline \multirow[t]{2}{*}{ C. edule relative abundance } & Linear $(1,45)$ & 0.95 & 0.3338 & 0.00 & 264.79 \\
\hline & Quadratic $(2,44)$ & 8.11 & 0.0010 & 23.62 & 253.02 \\
\hline
\end{tabular}

Table 3. Contribution of species to $>60 \%$ dissimilarity between low, intermediate and high hydrodynamically stressed depositfeeding assemblages using similarity percentage analysis based on the Bray-Curtis similarity of $\log (x+1)$-transformed standardized species abundance data. Presented abundances (ind. $\mathrm{m}^{-2}$ ) and relative abundances were not transformed

\begin{tabular}{|c|c|c|c|c|}
\hline \multirow[t]{2}{*}{ Species } & \multicolumn{2}{|c|}{ Abundance (relative abundance, \%) } & \multirow{2}{*}{$\begin{array}{c}\text { Contribution to } \\
\text { dissimilarity }\end{array}$} & \multirow{2}{*}{$\begin{array}{c}\text { Cumulative } \\
\text { percentage }(\%)\end{array}$} \\
\hline & Low & High & & \\
\hline Heteromastus filiformis & $978(28)$ & $3580(54)$ & 15.57 & 15.57 \\
\hline Pygospio elegans & $2750(14)$ & $526(5)$ & 15.03 & 30.59 \\
\hline Tubificoides sp. & $5771(26)$ & $2316(22)$ & 14.49 & 45.08 \\
\hline Aphelochaeta marioni & $3454(18)$ & $978(13)$ & 12.37 & 57.45 \\
\hline \multirow[t]{2}{*}{ Hydrobia ulvae } & $1020(6)$ & $68(1)$ & 10.86 & 68.31 \\
\hline & Low & Intermediate & & \\
\hline Aphelochaeta marioni & 3454 (18) & $1777(5)$ & 17.40 & 17.40 \\
\hline Tubificoides sp. & $5771(26)$ & $11983(42)$ & 15.60 & 33.01 \\
\hline Hydrobia ulvae & $1020(6)$ & $229(1)$ & 13.42 & 46.42 \\
\hline Heteromastus filiformis & $978(28)$ & 6205 (33) & 13.02 & 59.44 \\
\hline \multirow[t]{2}{*}{ Streblospio benedicti } & $612(3)$ & $211(1)$ & 9.54 & 68.98 \\
\hline & Intermediate & High & & \\
\hline Tubificoides sp. & $11983(42)$ & $2316(22)$ & 20.60 & 20.60 \\
\hline Heteromastus filiformis & $6205(33)$ & $3580(54)$ & 16.30 & 36.90 \\
\hline Pygospio elegans & 4589 (12) & $526(5)$ & 16.06 & 52.96 \\
\hline Aphelochaeta marioni & $1777(5)$ & $978(13)$ & 13.50 & 66.45 \\
\hline
\end{tabular}

Table 4. Influence of hydrodynamic stress on deposit-feeding assemblage-wide dietary dependence on microalgal carbon, living position in the sediment and development mode. Degrees of freedom are indicated next to the regression type (numerator, denominator). Regressions were based on the weighted averages for microalgal dietary dependence and the interpolated medians of development mode and living position scores of co-occurring species (see 'Materials and methods'). AIC: Akaike's information criterion

\begin{tabular}{|c|c|c|c|c|c|}
\hline \multirow{2}{*}{ Parameter } & \multirow{2}{*}{ Regression type } & \multicolumn{4}{|c|}{ - Regression statistics } \\
\hline & & $F$ & $\mathrm{p}$ & $\mathrm{R}_{\text {adj }}^{2}$ & AIC \\
\hline \multirow[t]{2}{*}{ Microalgal dietary dependence } & Linear $(1,46)$ & 28.91 & $<0.0001$ & 37.25 & -169.76 \\
\hline & Quadratic $(2,45)$ & 17.99 & $<0.0001$ & 41.96 & -172.56 \\
\hline \multirow{2}{*}{ Living position } & Linear $(1,46)$ & 29.75 & $<0.0001$ & 37.96 & 8.96 \\
\hline & Quadratic $(2,45)$ & 14.70 & $<0.0001$ & 36.82 & 10.50 \\
\hline \multirow{2}{*}{ Development mode } & Linear $(1,46)$ & 0.57 & 0.4559 & 0.00 & 14.18 \\
\hline & Quadratic $(2,45)$ & 10.08 & 0.0002 & 30.93 & -1.00 \\
\hline
\end{tabular}



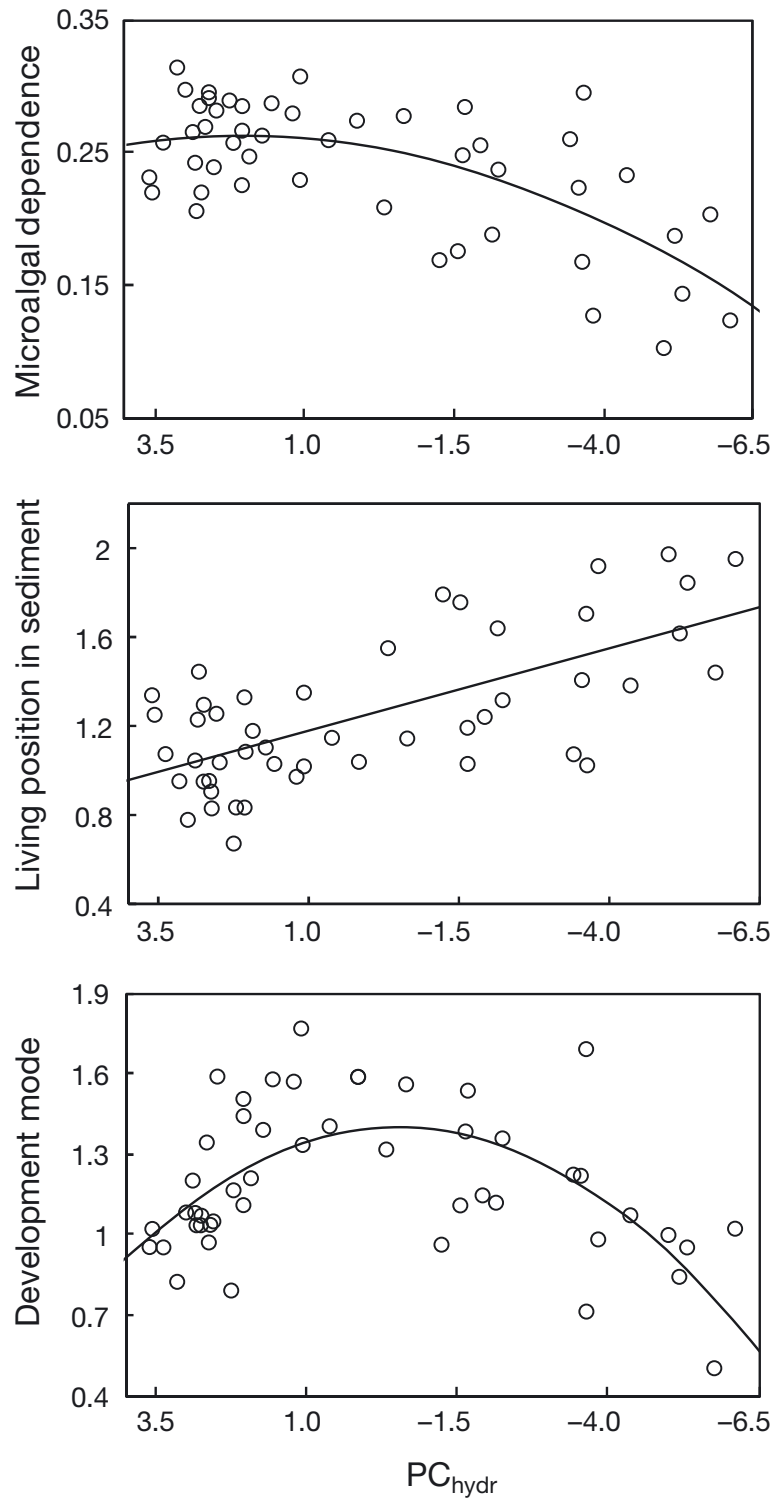

Fig. 3. Relationship between the degree of hydrodynamic stress $\left(\mathrm{PC}_{\mathrm{hydr}}\right)$ and assemblage-wide dependence on microalgal carbon, living position in the sediment and development mode. Increasing values of biological traits reflect a higher microalgal carbon dietary requirement, a deeper living position and a development mode which is less sensitive to disturbance at the sediment-water interface. Regression lines of the most reliable model are given (Table 4)

community and contributing most to the dissimilarity (Table 3). INDVAL assigned significant high indicator values for Streblospio benedicti (IV = 69.6), Hydrobia ulvae (IV =60.7), Aphelochaeta marioni (IV = 43.0) and Pygospio elegans (IV = 42.4) for low hydrodynamically stressed stations. Tubificoides sp. were typically ubiquitously present in stations with an intermediate $\mathrm{PC}_{\text {hydr }}$ value (IV = 38.8), whereas Heteromastus filiformis was highly indicative for high hydrodynamically stressed assemblages (IV $=39.9$ ). Further, the relation between $\mathrm{PC}_{\text {hydr }}$ and the proportional abundance of Cerastoderma edule revealed an intermediate optimum along the hydrodynamic stress gradient (Fig. 2, Table 2).

\section{Assemblage-wide biological traits}

The assemblage-wide contribution of microalgal carbon to the organisms' diets significantly decreased with increasing hydrodynamic stress. In contrast, a significant increase with hydrodynamic stress was present for the assemblage-wide living position in the sediment. A unimodal pattern along $\mathrm{PC}_{\mathrm{hydr}}$ was apparent for assemblage-wide development mode: on average, species with a more resistant development mode to disturbance of the benthic boundary layer predominantly occurred at intermediate hydrodynamically stressed stations in the mid intertidal (Table 4, Fig. 3).

\section{DISCUSSION}

The present study tested whether deposit-feeding macrobenthos demonstrated a unimodal diversity response to hydrodynamic stress, as predicted by the IDH (Connell 1978). In agreement with the IDH, low diversity (i.e. Shannon-Wiener index $H^{\prime}$ ) was found at high hydrodynamically stressed stations in the low intertidal. However, diversity peaked at low hydrodynamic stress occurring in the high intertidal and, hence, no diversity optimum at intermediate hydrodynamic stress was found. In addition, this survey corroborates recent studies which revealed that environmental stress or disturbance may differentially affect species richness, diversity and evenness (e.g. Kimbro \& Grosholz 2006, Scrosati \& Heaven 2007): species richness decreased with increasing hydrodynamic stress, whereas evenness was lowest at intermediate hydrodynamic stress and peaked at both low and high stress levels. Hence, both species richness, evenness and diversity should be measured to disentangle the driving forces of the relationship between environmental stress, diversity and ecosystem functioning. The lack of a diversity optimum at intermediate hydrodynamic stress corroborates the general observation from sandy beach and sandflat surveys (e.g. Degraer et al. 1999, Armonies \& Reise 2000, Giménez et al. 2005, 2006, Honkoop et al. 2006, Harriague \& Albertelli 2007), which suggests that environmental stress in tidal flat habitats is likely so high that competitive exclusion at the lower end of the stress gradient does not play a predominant role in determining deposit 
feeder diversity. Though we were unable to take all macrobenthos stressors into account (e.g. potential effects of top-down regulation of predation on benthic prey abundances, Zwarts \& Blomert 1992, van der Meer et al. 2000, Hiddink et al. 2002; variability in pore water metabolites associated with changes in the hydrodynamic regime, Raffaelli \& Hawkins 1996), the prevalent diversity pattern appears to be explained to a large extent by hydrodynamic stress sensu lato, and the congruent assemblage-wide shifts in biological traits suggest that species sorting in response to hydrodynamic stress is a main driver in structuring the deposit-feeding assemblages along the studied tidal flat. However, it should be noted that the macrobenthic community at the study site exhibits considerable seasonal variation (Ysebaert 2000, Van Colen et al. 2008, in press) and the observed patterns may therefore not necessarily be accurate over different seasons, since they were derived from samples collected in one season (i.e. spring).

Van de Koppel et al. (2001) demonstrated that interactions between the dominant microalgae at tidal flats, i.e. diatoms, and silt in the sediment induce positive feedback mechanisms between net silt accumulation and diatom growth in which diatoms decrease erosion of silt, which in turn results in higher diatom productivity. Consequently, more productive biofilms tend to develop on the more sheltered, stable and muddy upshore tidal flats (de Jong \& de Jonge 1995). The assemblage-wide shifts towards a higher dietary dependency on microalgal carbon and a shallower living position in a less hydrodynamically stressed environment suggest that surface-dwelling species that feed on diatoms are facilitated in the muddier high intertidal, while species less vulnerable to disturbance of the superficial sediment layer tend to disappear. This is reflected in the occurrence of different indicator species along the hydrodynamic stress gradient. The surface dwellers Hydrobia ulvae, Pygospio elegans and Streblospio benedicti were highly indicative of low hydrodynamically stressed assemblages, whereas Tubificoides sp. attained their highest absolute and relative abundances at intermediately stressed stations and Heteromastus filiformis, which feed only on a limited amount of microalgal carbon, was highly indicative of the assemblage in the hydrodynamically harsher low intertidal. The latter 2 species live and feed deeper in the sediment (i.e. subsurface deposit feeders) and may thus be expected to be less vulnerable to sediment resuspension at higher levels of hydrodynamic stress.

In addition to shifts in feeding and life habit, the community structure along the hydrodynamic stress gradient was also related to an assemblage-wide shift in development mode. On average, species with a pelagic larval stage or direct benthic development mode predominantly occurred at intermediate hydrodynamic stress levels in the mid intertidal. This zone was further characterized by the peak in the proportional abundance of the common edible cockle Cerastoderma edule, which corroborates the typical distribution pattern of suspension feeders in tidal flats: concentration in areas where bottom shear stress is relatively low and submersion time is sufficient to feed long enough to meet energetic requirements (Beukema 1976, Herman et al. 2001). These conditions were best in the mid intertidal zone of our study site, where tidal currents and thus bottom shear stress were drastically lower as compared to the lower intertidal, and submersion time was slightly longer as compared to the highest intertidal zone. C. edule was the most important suspension feeder, both in terms of biomass and abundance, at our study site (Ysebaert \& Herman 2002, Van Colen et al. 2008, Montserrat et al. 2008) and has been shown to significantly affect the benthic boundary layer by increasing bottom shear stress due to the physical structure of its shell and its biodiffusive activities that selectively remove fine material from the surface sediment (Ciutat et al. 2007, Montserrat et al. 2009). Due to these bioturbatory effects, $C$. edule has been shown to negatively affect macrobenthic populations (e.g. Jensen 1985, Flach \& De Bruin 1993, Flach 1996). According to the regressions by Flach (1996), cockle crawling and shaking will disturb $69 \pm 11,98 \pm$ 15 and $18 \pm 11 \%$ (mean $\pm \mathrm{SE}$ ) of the sediment to $\mathrm{a}$ depth of $\sim 3 \mathrm{~cm}$ within $10 \mathrm{wk}$ in the high, mid and low intertidal, respectively. The observed shifts in biological traits along the hydrodynamic stress gradient suggest that such severe interference from cockle bioturbation especially inhibits relatively surficial-living species and species with non-pelagic larval development, whereas species with direct benthic development and deeper-living species can cope better with this additional stress component. Consistently, the low evenness of intermediate hydrodynamically stressed assemblages, which experience high interference from cockle bioturbation, resulted from the dominance of the subsurface deposit feeders Heteromastus filiformis and Tubificoides sp., which together comprised $75 \%$ of the macrobenthic abundance in the mid intertidal.

Increased awareness of the importance of biophysical interactions in determining overall benthic community structure and diversity (e.g. Kimbro \& Grosholz 2006, Rabaut et al. 2007, Thrush et al. 2008) has led to the incorporation of facilitative interactions into recently updated environmental stress models (Bruno et al. 2003, Scrosati \& Heaven 2007). In addition, the results of the present study indicate that inhibitory biophysical interactions, such as interference by bioturbation, should be incorporated in environmental stress 
biodiversity models. In conclusion, our data do not support the IDH and indicate that alteration of the natural hydrodynamic regime will significantly alter tidal flat benthic community composition, diversity and functioning due to species sorting mechanisms.

Acknowledgements. This study was supported by the Institute for the Promotion of Innovation through Science and Technology in Flanders, Belgium (IWT Vlaanderen). The authors thank J. van Soelen and B. Koutstaal for their help with sampling and sample processing. K. Lambeets, W. Willems and B. Mercx are acknowledged for their advice on statistical models. This paper contributes to the Ghent University BBSea Project (GOA 01600705) and MarBEF, EU Network of Excellence (GOCE-CT-2003-505446). This is NIOOKNAW publication no. 4719.

\section{LITERATURE CITED}

Armonies W, Reise K (2000) Faunal diversity across a sandy shore. Mar Ecol Prog Ser 196:49-57

> Aronson RB, Precht WF (1995) Landscape patterns of reef coral diversity: a test of the intermediate disturbance hypothesis. J Exp Mar Biol Ecol 192:1-14

Austen MC, Widdicombe S (1998) Experimental evidence of effects of the heart urchin Brissopsis lyrifera on associated subtidal meiobenthic nematode communities. J Exp Mar Biol Ecol 222:219-238

Bertness MD (2007) Atlantic shorelines. Natural history and ecology, Princeton University Press, Princeton, NJ

Beukema JJ (1976) Biomass and species richness of the macrobenthic animals living on tidal flats of the Dutch Wadden Sea. Neth J Sea Res 10:236-261

Bremner J, Rogers SI, Frid CLJ (2003) Assessing functional diversity in marine benthic ecosystems: a comparison of approaches. Mar Ecol Prog Ser 254:11-25

Bruno JF, Stachowicz JJ, Bertness MD (2003) Inclusion of facilitation into ecological theory. Trends Ecol Evol 18: $119-125$

Ciutat A, Widdows J, Pope ND (2007) Effect of Cerastoderma edule density on near-bed hydrodynamics and stability of cohesive muddy sediments. J Exp Mar Biol Ecol 346: $114-126$

Clarke KR (1993) Non-parametric multivariate analysis of changes in community structure. Aust J Ecol 18:117-143

Clarke KR, Warwick RM (2001) Change in marine communities: an approach to statistical analysis and interpretation, 2nd edn. PRIMER-E, Plymouth

Commito JA, Thrush SF, Pridmore RD, Hewitt JE, Cummings VJ (1995) Dispersal dynamics in a wind-driven benthic system. Limnol Oceanogr 40:1513-1518

> Connell JH (1978) Diversity in tropical rain forests and coral reefs: high diversity of trees and corals is maintained only in a non-equilibrium state. Science 199:1302-1310

Connell JH, Hughes TP, Wallace CC, Tanner JE, Harms KE, Kerr AM (2004) A long-term study of competition and diversity of corals. Ecol Monogr 74:179-210

> Degraer S, Mouton I, De Neve L, Vincx M (1999) Community structure and intertidal zonation of the macrobenthos on a macrotidal, ultra-dissipative sandy beach: summer-winter comparison. Estuaries 22:742-752

de Jong DJ, de Jonge VN (1995) Dynamics and distribution of microphytobenthic chlorophyll $a$ in the western Scheldt Estuary (SW Netherlands). Hydrobiologia 311:21-30
Dekker R, Beukema JJ (1999) Relations of summer and winter temperatures with dynamics and growth of two bivalves, Tellina tenuis and Abra tenuis, on the northern edge of their intertidal distribution. J Sea Res 42:207-220

Dufrêne $M$, Legendre P (1997) Species assemblages and indicator species: the need for a flexible asymmetrical approach. Ecol Monogr 67:345-366

Eckert GL (2003) Effects of the planktonic period on marine population fluctuations. Ecology 84:372-383

Elliott M, Burdon D, Hemingway KL, Apitz SE (2007) Estuarine, coastal and marine ecosystem restoration: confusing management and science-a revision of concepts. Estuar Coast Shelf Sci 74:349-366

Flach EC (1996) The influence of the cockle, Cerastoderma edule, on the macrozoobenthic community of tidal flats in the Wadden Sea. PSZN I Mar Ecol 17:87-98

Flach EC, De Bruin W (1993) Effects of Arenicola marina and Cerastoderma edule on distribution, abundance and population structure of Corophium volutator in Gullmarsfjorden, western Sweden. Sarsia 78:105-118

> Fujii T, Raffaelli D (2008) Sea-level rise, expected environmental changes, and responses of intertidal benthic macrofauna in the Humber estuary, UK. Mar Ecol Prog Ser 371:23-35

Giménez L, Borthagaray AI, Rodriguez M, Brazeiro A, Dimitriadis C (2005) Scale-dependent patterns of macrofaunal distribution in soft-sediment intertidal habitats along a large-scale estuarine gradient. Helgol Meeresunters 59: $224-236$

> Giménez L, Dimitriadis C, Carranza A, Borthagaray AI, Rodriguez M (2006) Unravelling the complex structure of a benthic community: a multiscale-multianalytical approach to an estuarine sandflat. Estuar Coast Shelf Sci 68:462-472

Goodall DW (1954) Objective methods for the classification of vegetation: an essay in the use of factor analysis. Aust J Bot 2:304-324

Graveland J (2005) Fysische en ecologische kennis en modellen voor de Westerschelde. Report RIKZ/2005.018, Rijkswaterstaat, Middelburg

> Gray JS (1997) Marine biodiversity: patterns, threats and conservation needs. Biodivers Conserv 6:153-175

Günther CP (1992) Dispersal of intertidal invertebrates: A strategy to react to disturbances of different scales? Neth J Sea Res 30:45-56

> Halpern BS, Walbridge S, Selkoe KA, Kappel CV and others (2008) A global map of human impact on marine ecosystems. Science 319:948-952

Hampel H, Cattrijsse A, Elliott M (2005) Feeding habits of young predatory fishes in marsh creeks situated along the salinity gradient of the Schelde estuary, Belgium and the Netherlands. Helgol Meeresunters 59:151-162

Harriague AC, Albertelli G (2007) Environmental factors controlling macrofaunal assemblages on six microtidal beaches of the Ligurian Sea (NW Mediterranean). Estuar Coast Shelf Sci 73:8-16

> Herman PMJ, Middelburg JJ, Widdows J, Lucas CH, Heip CHR (2000) Stable isotopes as trophic tracers: combining field sampling and manipulative labelling of food resources for macrobenthos. Mar Ecol Prog Ser 204:79-92

> Herman PMJ, Middelburg JJ, Heip CHR (2001) Benthic community structure and sediment processes on an intertidal flat: results from the ECOFLAT project. Cont Shelf Res 21:2055-2071

Hiddink JG, ter Hofstede R, Wolff WJ (2002) Predation of intertidal infauna on juveniles of the bivalve Macoma balthica. J Sea Res 47:141-159 
Honkoop PJC, Pearson GB, Lavaleye MSS, Piersma T (2006) Spatial variation of the intertidal sediments and macrozoobenthic assemblages along Eighty-mile Beach, northwestern Australia. J Sea Res 55:278-291

> Jensen KT (1985) The presence of the bivalve Cerastoderma edule affects migration, survival and reproduction of the amphipod Corophium volutator. Mar Ecol Prog Ser 25: 269-277

Johnson JB, Omland KS (2004) Model selection in ecology and evolution. Trends Ecol Evol 19:101-108

> Jones CG, Lawton JH, Shachak M (1994) Organisms as ecosystem engineers. Oikos 69:373-386

Kennish MJ (2002) Environmental threats and environmental future of estuaries. Environ Conserv 29:78-107

Kimbro DL, Grosholz ED (2006) Disturbance influences oyster community richness and evenness, but not diversity. Ecology 87:2378-2388

Mackey RL, Currie DJ (2001) The diversity-disturbance relationship: Is it generally strong and peaked? Ecology 82: 3479-3492

- Menge BA, Sutherland JP (1987) Community regulation: variation in disturbance, competition, and predation in relation to environmental stress and recruitment. Am Nat 130:730-757

> Meysman FJR, Middelburg JJ, Heip CHR (2006) Bioturbation: a fresh look at Darwin's last idea. Trends Ecol Evol 21: 688-695

Montserrat F, Van Colen C, Degraer S, Ysebaert T, Herman PMJ (2008) Benthic community-mediated sediment dynamics. Mar Ecol Prog Ser 372:43-59

Montserrat F, Van Colen C, Provoost P, Milla M and others (2009) Sediment segregation by biodiffusing bivalves. Estuar Coast Shelf Sci 83:379-391

Paine RT (1966) Food web complexity and species diversity. Am Nat 100:65-75

Rabaut M, Guilini K, Van Hoey G, Magda V, Degraer S (2007) A bio-engineered soft-bottom environment: the impact of Lanice conchilega on the benthic species-specific densities and community structure. Estuar Coast Shelf Sci 75: 525-536

Raffaelli D, Hawkins S (1996) Intertidal ecology. Chapman \& Hall, London

Reise K (1985) Tidal flat ecology: an experimental approach to species interactions. Springer-Verlag, Berlin

Schratzberger M, Warwick RM (1998) Effects of the intensity and frequency of organic enrichment on two estuarine nematode communities. Mar Ecol Prog Ser 164:83-94

Schratzberger M, Warwick RM (1999) Differential effects of various types of disturbances on the structure of nematode assemblages: an experimental approach. Mar Ecol Prog Ser 181:227-236

Scrosati R, Heaven C (2007) Spatial trends in community richness, diversity, and evenness across rocky intertidal environmental stress gradients in eastern Canada. Mar Ecol Prog Ser 342:1-14

Somerfield PJ, Clarke KR (1995) Taxonomic levels, in marine community studies, revisited. Mar Ecol Prog Ser 127: $113-119$

Sousa ME (1979) Disturbance in marine intertidal boulder fields: the nonequlibrium maintenance of species diversity. Ecology 60:1225-1239

> Stachowicz JJ, Bruno JF, Duffy JE (2007) Understanding the effects of marine biodiversity on communities and ecosystems. Annu Rev Ecol Syst 38:739-765

Tamaki A (1987) Comparison of resistivity to transport by wave action in several polychaete species on an intertidal sand flat. Mar Ecol Prog Ser 37:181-189
Thrush SF, Coco G, Hewitt JE (2008) Complex positive connections between functional groups are revealed by neural network analysis of ecological time series. Am Nat 171:669-677

Van Colen C, Montserrat F, Vincx M, Herman PMJ, Ysebaert T, Degraer S (2008) Macrobenthic recovery from hypoxia in an estuarine tidal mudflat. Mar Ecol Prog Ser 372:31-42

Van Colen C, Montserrat F, Vincx M, Herman PMJ, Ysebaert T, Degraer S (2010) Long-term divergent tidal flat community recovery following hypoxia-induced mortality. Mar Pollut Bull 60:178-186

van de Koppel J, Herman PMJ, Thoolen P, Heip CHR (2001) Do alternate stable states occur in natural ecosystems? Evidence from a tidal flat. Ecology 82:3449-3461

> van der Meer J, Beukema JJ, Dekker R (2000) Population dynamics of two marine polychaetes: the relative role of density dependence, predation, and winter conditions. ICES J Mar Sci 57:1488-1494

> van Oevelen D, Soetaert K, Middelburg JJ, Herman PMJ and others (2006) Carbon flows through a benthic food web: integrating biomass, isotope and tracer data. J Mar Res 64: 453-482

> Volkenborn N, Reise K (2007) Effects of Arenicola marina on polychaete functional diversity revealed by large-scale experimental lugworm exclusion. J Sea Res 57:78-88

> Volkenborn N, Hedtkamp SIC, van Beusekom JEE, Reise K (2007) Effects of bioturbation and bioirrigation by lugworms (Arenicola marina) on physical and chemical sediment properties and implications for intertidal habitat succession. Estuar Coast Shelf Sci 74:331-343

> Warwick RM, Clarke KR (1993) Comparing the severity of disturbance: a meta analysis of marine macrobenthic community data. Mar Ecol Prog Ser 92:221-231

Widdicombe S, Austen MC (1999) Mesocosm investigation into the effects of bioturbation on the diversity and structure of a subtidal macrobenthic community. Mar Ecol Prog Ser 189:181-193

Widdicombe S, Austen MC (2001) The interaction between physical disturbance and organic enrichment: an important element in structuring benthic communities. Limnol Oceanogr 46:1720-1733

Widdows J, Brinsley MD, Bowley N, Barrett C (1998) A benthic annular flume for in situ measurement of suspension feeding/biodeposition rates and erosion potential of intertidal cohesive sediments. Estuar Coast Shelf Sci 46: 27-38

Widdows J, Lucas JS, Brinsley MD, Salkeld PN, Staff FJ (2002) Investigation of the effects of current velocity on mussel feeding and mussel bed stability using an annular flume. Helgol Mar Res 56:3-12

Ysebaert T (2000) Macrozoobenthos and waterbirds in the estuarine environment: spatio-temporal patterns at different scales. PhD thesis, University of Antwerp

> Ysebaert T, Herman PMJ (2002) Spatial and temporal variation in benthic macrofauna and relationships with environmental variables in an estuarine, intertidal soft-sediment environment. Mar Ecol Prog Ser 244:105-124

Ysebaert T, Herman PMJ, Meire P, Craeymeersch J, Verbeek H, Heip CHR (2003) Large-scale spatial patterns in estuaries: estuarine macrobenthic communities in the Schelde estuary, NW Europe. Estuar Coast Shelf Sci 57:335-355

Zar JH (1996) Biostatistical analysis, 3th edn. Prentice Hall, Upper Saddle River, NJ

Zwarts L, Blomert AM (1992) Why knot Calidris canutus take medium-sized Macoma balthica when six prey species are available. Mar Ecol Prog Ser 83:113-128 


\section{Appendix 1.}

Table A1. Macrobenthic species present at the study site. Biological traits for deposit feeders are given together with their scores, used to analyze assemblage-wide biological trait displacements along the $\mathrm{PC}_{\mathrm{hydr}}$. Increasing scores for development mode and living position in the sediment indicate a lower sensitivity to hydrodynamic stress. Scores for living position in the sediment are based on $20 \mathrm{~cm}$ deep vertical profiles taken at the study site $(\mathrm{n}=10$; slices $=<2,2-5,5-20 \mathrm{~cm})$. Species were assigned a living position score of 0,1 or 2 if they attained their highest abundance in the upper, middle or lower depth class, respectively. Species were assigned a development mode score of 0,1 or 2 if they have a non- or limited pelagic larval development, a pelagic larval development or direct benthic development, respectively. See text for more details. As the focus of this study is on deposit feeders, no in-depth analyses were performed on suspension feeders or scavangers/omnivores; these are included in the table to inform the reader of other species present in the community. D: direct benthic development; P: pelagic larval development; NP: non-pelagic or limited pelagic larval development; nd: not determined and omitted from the analyses

\begin{tabular}{|c|c|c|c|c|}
\hline \multirow[t]{2}{*}{ Species } & \multirow{2}{*}{$\begin{array}{l}\text { Microalgal dependence } \\
\text { ( } \Delta \text {-ratio) }\end{array}$} & \multirow[t]{2}{*}{ Development mode } & \multicolumn{2}{|c|}{ Living position } \\
\hline & & & Depth $(\mathrm{cm})$ & Score \\
\hline \multicolumn{5}{|l|}{ Deposit feeders } \\
\hline Abra tenuis & nd & $\mathrm{D}(2)$ & $2-5$ & 1 \\
\hline Aphelochaeta marioni & 0.30 & NP $(0)$ & $2-5$ & 1 \\
\hline Arenicola marina & nd & NP (0) & $>5$ & 2 \\
\hline Corophium volutator & nd & $\mathrm{D}(2)$ & $0-2$ & 1 \\
\hline Heteromastus filiformis & 0.09 & $\mathrm{P}(1)$ & $>5$ & 2 \\
\hline Hydrobia ulvae & 0.57 & $\mathrm{P}(1)$ & $0-2$ & 0 \\
\hline Macoma balthica & 0.44 & $\mathrm{P}(1)$ & $2-5$ & 1 \\
\hline Malacoceros sp. & 0.31 & $P(1)$ & $0-2$ & 0 \\
\hline Nereis diversicolor & 0.43 & NP (0) & $2-5$ & 1 \\
\hline Polydora cornuta & 0.30 & $\mathrm{P}(1)$ & $0-2$ & 0 \\
\hline Pygopsio elegans & 0.23 & $\mathrm{P}(1)$ & $0-2$ & 0 \\
\hline Scrobicularia plana & 0.00 & $\mathrm{P}(1)$ & $>5$ & 2 \\
\hline Streblospio benedicti & 0.14 & $\mathrm{P}(1)$ & $0-2$ & 0 \\
\hline Tubificoides sp. & 0.35 & $\mathrm{D}(2)$ & $2-5$ & 1 \\
\hline \multicolumn{5}{|l|}{ Suspension feeders } \\
\hline \multicolumn{5}{|l|}{ Cerastoderma edule } \\
\hline \multicolumn{5}{|l|}{ Mysella bidentata } \\
\hline \multicolumn{5}{|l|}{ Predators/scavengers } \\
\hline \multicolumn{5}{|l|}{ Anaitides mucosa } \\
\hline \multicolumn{5}{|l|}{ Eteone longa } \\
\hline \multicolumn{5}{|l|}{ Nephtys cirrosa } \\
\hline Retusa obtusa & & & & \\
\hline
\end{tabular}

Editorial responsibility: Lisandro Benedetti-Cecchi, Pisa, Italy
Submitted: September 30, 2009; Accepted: February 5, 2010 Proofs received from author(s): April 27, 2010 